\title{
Health Care for People with Disabilities in the Unified Health System in Brazil: A Scoping Review
}

\author{
Márcia Andrea Oliveira da Cunha ${ }^{1}$, Helena Fernandes Santos ${ }^{2}$, Maria Eduarda Lima de Carvalho ${ }^{3}$, \\ Gabriella Morais Duarte Miranda ${ }^{4,5}$, Maria do Socorro Veloso de Albuquerque ${ }^{4,5}$, Raquel Santos de Oliveira ${ }^{4}$, \\ Adrião Filho Cavalcanti de Albuquerque ${ }^{6}$, Loveday Penn-Kekana ${ }^{7}$, Hannah Kuper ${ }^{7, *}$ and Tereza Maciel Lyra ${ }^{5}$
}

Citation: da Cunha, M.A.O.; Santos, H.F.; de Carvalho, M.E.L.; Miranda, G.M.D.; de Albuquerque, M.d.S.V.; de Oliveira, R.S.; de Albuquerque, A.F.C.; Penn-Kekana, L.; Kuper, H.; Lyra, T.M. Health Care for People with Disabilities in the Unified Health System in Brazil: A Scoping Review. Int. J. Environ. Res. Public Health 2022, 19, 1472. https:// doi.org/10.3390/ijerph19031472

Academic Editors: Carme Borrell, Davide Malmusi and

Amaia Bacigalupe

Received: 17 December 2021

Accepted: 21 January 2022

Published: 28 January 2022

Publisher's Note: MDPI stays neutral with regard to jurisdictional claims in published maps and institutional affiliations.

Copyright: (C) 2022 by the authors. Licensee MDPI, Basel, Switzerland. This article is an open access article distributed under the terms and conditions of the Creative Commons Attribution (CC BY) license (https:// creativecommons.org/licenses/by/ $4.0 /)$.
1 Faculty of Medical Sciences, University of Pernambuco, Recife 50100-130, Brazil; marcia.oliveira@upe.br

2 Political Science Department, Federal University of Pernambuco, Recife 50070-460, Brazil; helenafsantos8@gmail.com

3 Post-Graduation in Public Health, Aggeu Magalhães Institute, FIOCRUZ, Recife 50670-420, Brazil; melc.duda@gmail.com

4 Academic Area of Public Health, Center for Medical Sciences, Federal University of Pernambuco, Recife 50070-460, Brazil; gabymduarte21@gmail.com (G.M.D.M.); msoveloso@gmail.com or maria.valbuquerque@ufpe.br (M.d.S.V.d.A.); raquelsoliveira78@yahoo.com.br (R.S.d.O.)

5 Department of Collective Health, Aggeu Magalhães Institute, FIOCRUZ, Recife 50670-420, Brazil; tereza.lyra@fiocruz.br

6 Recife Health Department, Recife 50080-000, Brazil; adriao@recife.pe.gov.br

7 Faculty of Epidemiology and Population Health, London School of Hygiene \& Tropical Medicine, London WC1E 7HT, UK; loveday.penn-kekana@lshtm.ac.uk

* Correspondence: hannah.kuper@lshtm.ac.uk

\begin{abstract}
People with disabilities have greater need for healthcare on average, but often face barriers when accessing these services. The Brazilian government launched the National Health Policy for People with Disabilities (PNSPD) in 2002 to address this inequality. PNSPD has six areas of focus: quality of life, impairment prevention, comprehensive health care, organization and functioning of health services, information mechanisms, and training of human resources. The aim of this article was to undertake a scoping review to assess the evidence on the experience of people with disabilities in Brazil with respect to the six themes of the PNSPD. The scoping review included articles published between 2002 and 2019, from four electronic databases: PUBMED/MEDLINE, LILACS, Science Direct, and Scielo. In total, 8076 articles were identified, and after review of titles, abstracts, and full texts by two independent reviewers, 98 were deemed eligible for inclusion. The evidence was relatively limited in availability and scope. However, it consistently showed large gaps in delivery of healthcare to people with disabilities across the six dimensions considered. There was lack of actions aimed at promoting quality of life; insufficient professional training about disability; little evidence on the health profile of people with disabilities; large gaps in the availability of care due to widespread physical, informational, and attitudinal barriers; and poor distribution of the supply and integration of services. In conclusion, the policy framework in Brazil is supportive of the inclusion of people with disabilities in health services; however, large inequalities remain due to poor implementation of the policy into practice.
\end{abstract}

Keywords: disability; healthcare access; health policy; Brazil

\section{Introduction}

People with disabilities include those who have long-term physical, mental, intellectual, or sensory impairments that, in interaction with various barriers, may hinder their full and effective participation in society on an equal basis with others (definition of the UN Convention of the Rights of Persons with Disabilities) [1]. Globally, there are at least 1 billion people with disabilities, making up $15 \%$ of the world's population [2]. People with disabilities face widespread barriers and exclusions, including with respect to healthcare, 
and this contributes to their inequalities in health status and healthcare access [2,3]. It is therefore important to develop policies and programmes to support people with disabilities to overcome barriers, reduce inequalities, and realise their rights, including with respect to healthcare access.

Brazil can potentially provide a good practice example, as it has a progressive policy that should support the inclusion of people with disabilities in the health system. According to the Brazilian Federal Constitution of 1988, it is the duty of the State to take care of health and public assistance and the protection and guarantee of rights of people with disabilities [4]. Furthermore, in 2002 the National Health Policy for Persons with Disabilities (Política Nacional de Saúde da Pessoa com Deficiência-PNSPD) was implemented by the Ministry of Health after intensive lobbying from the disability community to support access to holistic healthcare for people with disabilities [5]. The PNSPCD had aims of universality, integrality, and equity, and it provides specific guidelines in the implementation of the health care policy relevant to people with disabilities. The PNSPD defined six areas of focus: (1) promotion of quality of life; (2) impairment prevention; (3) comprehensive health care; (4) organization and functioning of care services for persons with disabilities; (5) expansion and strengthening of information mechanisms; and (6) human resources training. This commitment to the right to healthcare for people with disabilities was reinforced by the ratification of the UNCRPD in Brazil in 2008 and again by the launching of the National Plan for the Rights of Persons with Disabilities-Living without Limits in 2011 [6]. The latter had the participation of more than 15 ministries and the National Council for the Rights of Persons with Disabilities (Conade), involved all federal entities, and had predicted investments of 7.6 billion reais (approximately 1.3 billion USD) until 2014 [6]. Specific commitments were also made to expand rehabilitation services and the provision of assistive technology [7]. This focus is important, as there are at least 17.3 million people with disabilities in Brazil, with a relatively even split of people with visual, hearing, lower-limb physical, upper-limb physical, or psychological impairments [8].

The policy framework in Brazil is therefore supportive of the right to healthcare for people with disabilities. However, good policy does not automatically translate into good practice and good outcomes. The effective implementation of a public policy depends on sufficient allocation of resources, intersectoral programmatic support, the inclusion of different interest groups in decision-making, and, perhaps most importantly, on the priority given by governments to the issue in question. These factors have been challenging in recent years in Brazil with the financial crisis and the shift towards neo-liberal politics. Yet, there has not been an assessment in Brazil of the realisation of the right to healthcare for people with disabilities, as set out in the PNSPD guidelines. We therefore undertook a scoping review to assess the evidence on the experience of people with disabilities in Brazil with respect to the six themes of the PNSPD guidelines: promotion of quality of life, impairment prevention, comprehensive health care, organization and functioning of health services, information mechanisms, and training of human resources.

\section{Materials and Methods}

A scoping review was undertaken to identify eligible original articles that provided evidence about healthcare for people with disabilities within the Brazilian health system. Eligible articles included qualitative or quantitative studies and were published in Portuguese, English, or Spanish between 2002 and 2019. Review articles, editorials, commentaries, and dissertations/theses were excluded. A protocol (PRISMA-ScR) was developed and published in the Open Science Framework (OSF. Available online: https://osf.io/8mghk/, accessed on 26 January 2022) [9].

Searches were performed in four electronic databases: PUBMED/MEDLINE, LILACS, Science Direct, and Scielo. The selection of descriptors was carried out through the Health Sciences Descriptors database-DeSC — and through MeSH (Medical Subject Headings). The following terms were used: Pessoas com deficiência, Pessoa com deficiência, Portador de deficiência, Portadores de deficiência, Pessoas com deficiências, Pessoa com deficiências, 
Portador de deficiências, Portadores de deficiências, Disabled Persons, People with Disabilities, People with Disability, Persons with Disabilities, Persons with Disability, Handicapped, Integralidade, Assistência Integral, Atenção à saúde, Atenção primária, Atenção secundária, Atenção terciária, and Atendimento Integral.

We undertook screening of titles, abstracts, and full texts to identify eligible articles. All screening was performed independently by two reviewers, with resolution of disagreements through consultation with a third reviewer at all stages. Before screening, 100 articles were selected to verify the degree of convergence between the reviewers, using the KAPPA index, which reached a value of 0.773 , which indicated substantive agreement between the two reviewers [10].

Data were extracted from the eligible publications, including the methodological procedures of the studies, scope and location, type of study, research design, participant selection criteria, sample size and/or population, criteria for defining the sample size, period of data collection, characteristics of the studied population (gender, age, race, education, income), and levels of health care considered in the research. Narrative review was undertaken of the data to consider how health care for people with disabilities has been addressed in the scientific literature in Brazil, based on the guidelines of the PNSPD. Studies that addressed more than one category were grouped according to the objectives and main results presented.

Although in the PNSPD, the "Comprehensive health care for people with disabilities" and "Organization and operation of care services for people with disabilities" presented as separate axes [5], in this study, they were analysed together from the perspective of comprehensiveness of health care. This is because disability inclusion is understood to have two dimensions: (1) access to specific services offered in a well-defined health service facility and (2) access to comprehensive healthcare conceived in a broad way, which often takes place in a network of health services either because the various health technologies are distributed in a wide range of services or because the improvement of conditions of life is a task for an intersectoral effort.

\section{Results}

Overall, 8076 articles were identified (433 Science Direct, 684 Scielo, 2444 LILACS, and 4515 PUBMED/MEDLINE), of which 638 abstracts were screened, 221 full texts reviewed, and 98 articles selected for inclusion (5 PUBMED/MEDLINE articles, 27 Scielo articles, and 66 LILACS articles) (Figure 1).

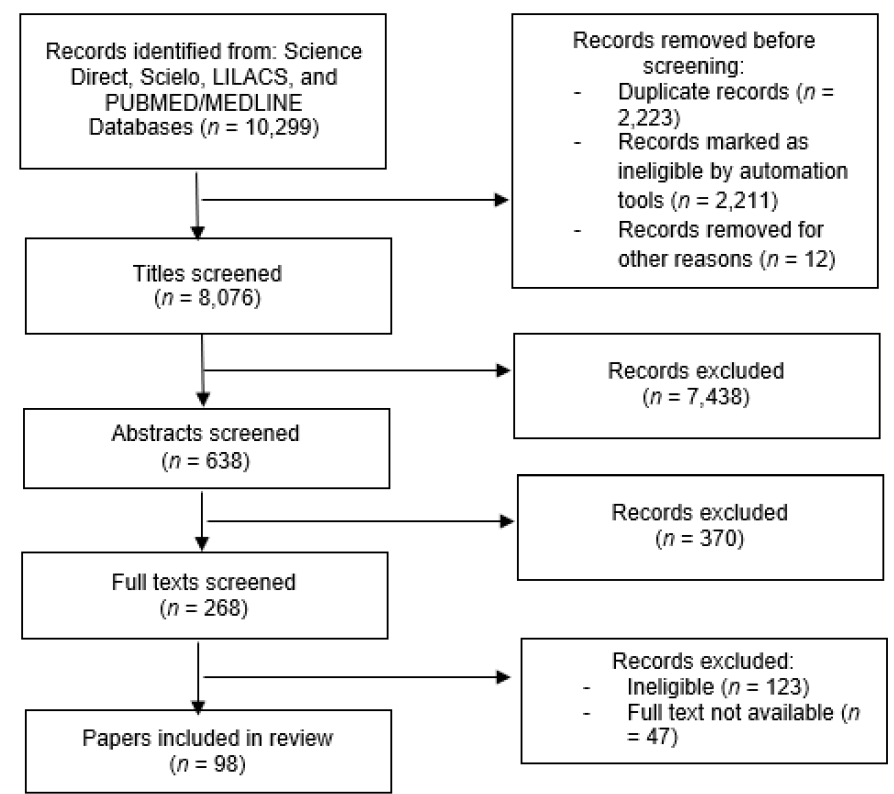

Figure 1. Study selection PRISMA flow diagram. 


\subsection{Study Characteristics}

The characteristics of included studies are described in Table 1.

Table 1. Characteristics of studies included in the scoping review.

\begin{tabular}{|c|c|c|}
\hline Variable & Level & $\begin{array}{c}\text { Percentage of Eligible } \\
\text { Studies }(n=98)\end{array}$ \\
\hline \multirow{5}{*}{ Study location } & National & $2 \%$ \\
\hline & Regional/district & $4 \%$ \\
\hline & State & $15 \%$ \\
\hline & Local & $39 \%$ \\
\hline & Municipal & $40 \%$ \\
\hline \multirow{4}{*}{ Region } & Southeast & $44 \%$ \\
\hline & Northeast & $33 \%$ \\
\hline & South & $18 \%$ \\
\hline & Mixed/other & $5 \%$ \\
\hline \multirow{3}{*}{ Healthcare level } & Primary healthcare & $39 \%$ \\
\hline & Specialist services & $54 \%$ \\
\hline & Mixed/other & $7 \%$ \\
\hline \multirow{5}{*}{ Disability type } & All & $40 \%$ \\
\hline & Hearing & $32 \%$ \\
\hline & Visual & $5 \%$ \\
\hline & Intellectual & $3 \%$ \\
\hline & Multiple & $2 \%$ \\
\hline \multirow{4}{*}{ Participant type } & Person with disability & $55 \%$ \\
\hline & Health professional & $26 \%$ \\
\hline & Health unit & $7 \%$ \\
\hline & Mixed/other & $12 \%$ \\
\hline \multirow{4}{*}{ Participant age } & Child/adolescent & $16 \%$ \\
\hline & Adult/elderly & $29 \%$ \\
\hline & Mixed & $12 \%$ \\
\hline & Not applicable & $43 \%$ \\
\hline \multirow{3}{*}{ Participant gender } & Mixed & $63 \%$ \\
\hline & Female only & $3 \%$ \\
\hline & Not applicable & $34 \%$ \\
\hline \multirow{3}{*}{ Study method } & Quantitative & $48 \%$ \\
\hline & Qualitative & $42 \%$ \\
\hline & Mixed & $10 \%$ \\
\hline \multirow{3}{*}{ Data collection } & Primary & $77 \%$ \\
\hline & Secondary & $16 \%$ \\
\hline & Mixed & $7 \%$ \\
\hline \multirow{4}{*}{ Sample size } & $1-100$ & $61 \%$ \\
\hline & $101-1000$ & $26 \%$ \\
\hline & $1001+$ & $10 \%$ \\
\hline & NA & $3 \%$ \\
\hline \multirow{2}{*}{ Participant selection criteria specified } & Yes & $81 \%$ \\
\hline & No/NA & $19 \%$ \\
\hline
\end{tabular}

In terms of location, most studies were carried out at the municipal (40\%) or local (39\%) level. Almost all studies were undertaken in one of three regions: southeast (44\%), northeast $(33 \%)$, and South (18\%). There was a relatively even split in studies focussed on primary $(39 \%)$ or specialist $(54 \%)$ healthcare. Studies focussed mostly on all disabilities (40\%) or hearing (32\%) impairments, while other categories received little attention. The study population was usually people with disabilities (55\%) rather than healthcare professionals $(26 \%)$. Most studies focussed on both males and females, and more studies addressed adults/older people rather than children. There was an even split between quantitative 
(48\%) and qualitative (42\%) approaches, and most studies used primary data sources (77\%). The majority of studies provided participant selection criteria (81\%). Sample size was generally rather small, as $61 \%$ of studies included 100 or fewer participants.

\subsection{PNSPD Studies and Guidelines}

"Comprehensive health care for people with disabilities" and "Organization and operation of care services for people with disabilities" sectors were combined and comprised $44 \%$ of all articles identified (Table 2). A quarter (25\%) of articles focussed on promotion of quality of life for people with disabilities, while less literature was available on the topics of impairment prevention $(12 \%)$, training $(11 \%)$, and information mechanisms $(8 \%)$.

Table 2. Studies grouped according to PNSPD guidelines.

\begin{tabular}{|c|c|c|}
\hline PNSPD Guidelines & Studies & References \\
\hline Promotion of quality of life for people with disabilities & $25 \%$ & {$[11-34]$} \\
\hline $\begin{array}{c}\text { Comprehensive health care for people with disabilities } \\
\text { and organization and operation of care services for people } \\
\text { with disabilities }\end{array}$ & $44 \%$ & [35-77] \\
\hline Impairment prevention & $12 \%$ & [78-89] \\
\hline Expansion and strengthening of information mechanisms & $8 \%$ & [90-97] \\
\hline $\begin{array}{c}\text { Training human resources for assistance to people } \\
\text { with disabilities }\end{array}$ & $11 \%$ & [98-108] \\
\hline
\end{tabular}

\subsection{Narrative Review of the Studies}

\subsubsection{Promoting the Quality of Life of People with Disabilities}

Twenty-four (25\%) articles focussed on promotion of the quality of life of people with disabilities, including through provision of assistive technology (six articles); elimination of barriers that hinder the effective integration and inclusion (nine articles); inclusion and social participation (two articles); and evaluation of quality of life (five articles) [11-34]. Most of these studies took place at the primary care level and included a range of types of disabilities.

Six studies focussed on the importance of assistive technology to promote quality of life $[11,12,21,28,31,32]$. Of these, three studies highlighted the need to expand the availability of assistive technologies in the Public Health System (Sistema Unico de Saúde-SUS) and to offer equipment adapted to the specific demands of people with disabilities (wheelchairs, supply and replacement of hearing aids, devices for low vision, and equipment for the adaptation of children with cerebral palsy in everyday life) $[11,12,21]$. One study showed a positive correlation between the systematic use of hearing aids with the development of children's hearing and language [11]. A final study highlighted the positive partnership between the State Government and the Public Ministry in offering wheelchairs in Natal, Rio Grande do Norte [12].

Nine articles addressed the barriers to the inclusion of people with disabilities in health services, and these studies were carried out at the primary care level, hospitals, and rehabilitation services. Lack of accessibility of health units was found to be an important barrier [11,13,14,17-20,23,34]. Two studies showed that hospitals and rehabilitation services were not physically accessible, and they highlighted the need for access ramps, door widening, signage, elevators, and handrails [12,20]. Studies at the primary care level paint an even grimmer picture. A nationwide study carried out in 41 municipalities with more than 100,000 inhabitants and containing 240 primary healthcare facilities concluded that $60 \%$ of these units are inadequate for the access of older people and people with disabilities [17]. Three studies focussed on the accessibility of health services to people with hearing impairment $[47,102,106]$. They showed that the lack of training and the nonadoption of the Brazilian Sign Language in primary care and specialized health units was the main barriers that limit their access to health services. Two further studies highlighted 
the barriers to accessibility of people with mobility impairments due to the lack of adapted public transport and the precarious conditions of the sidewalks $[13,23]$.

People with disabilities are not a homogenous group, and three studies explored how intersectionality influenced the experiences in terms of quality of life $[25,27,33]$. A quantitative study [26] showed that quality of life of people with disabilities was negatively associated with difficulties with mobility, work, money, information, leisure, and sexual life. Poor people with disabilities may therefore be particularly vulnerable, and addressing healthcare barriers is only one component for improving quality of life. Another study confirmed these findings, indicating that the greater the social inequality, the lower the level of inclusion experienced by people with disabilities [25]. On the other hand, a third study highlighted the potential of health services to supporting quality of life [30]. It showed that children with cerebral palsy and consequently generally high care needs are more likely to be functionally independent and experience a good quality of life if they have good access to relevant services.

\subsubsection{Impairment Prevention}

Impairment prevention was addressed in 12 studies [78-89]. These studies included consideration of neonatal hearing screening (NHS-nine studies); risk factors for deafness (one); early and late rehabilitation in deaf children and adolescents (one); early diagnosis of visual impairment in children (one); and prevention of visual impairment in people with diabetes (one). Research on the NHS was carried out in specialized outpatient services, rehabilitation services and hospitals/maternity hospitals [83]. The study showed that NHS coverage was below 25\% in north-eastern Brazil, which is below the recommendations of the Ministry of Health. These levels should be raised, as there is positive correlation between the performance of NHS and the reduction of time to start early intervention and prevention of deafness. One study [86] explored the identification of risk factors for deafness and concluded that only $54 \%$ of physicians provide adequate guidance on the subject.

3.3.3. Comprehensive Health Care and Organization and Operation of Care Services for People with Disabilities

Comprehensive health care and organization and operation of care services for people with disabilities was considered by 43 studies [35-77]. Nine studies examined access of people with disabilities to basic health services and identified a range of challenges, including low supply of basic services and specialized reference services for physical rehabilitation, insufficient organization of referrals and coordination of care, and lack of information about the care network for people with disabilities in addition to the lack of accessibility of facilities already described $[38,39,41,46,47,64,65,71,77]$. Consequently, people with disabilities had worse health outcomes, including a higher number of admissions to a psychiatric hospital and lower levels of breast self-exams and cervical cytopathological tests. One study considered specifically what changes are needed to primary care facilities to be able to meet the needs of people with disabilities and concluded that changes to structures and work processes are required [58]. Another study focussed on improvements needed in the coordination of health care and family and community guidance to improve care of children with disabilities in primary health settings [57]. Certain groups may face particular difficulties accessing health services, including older people with disabilities and people who are deaf, and they may need specific targeting with services and/or information $[41,47,48]$. A good practice example was also identified as provision of home visits for children with disabilities, which was shown to overcome some barriers and promote inclusion in health services [40].

A set of five papers focussed specifically on oral health care for people with disabilities at the primary health level, as the availability of these services is a specific commitment within SUS $[38,45,46,64,66]$. Again, people with disabilities experienced a range of difficulties in accessing these services due to low number of dental professionals with training and 
skills around disability, delay in scheduling appointments, and lack of general anaesthesia for specific cases. These health system failures resulted in worse oral health for people with disabilities; one study found that $76 \%$ of people with disabilities have difficulty in receiving care; $85 \%$ only seek urgent care; and $56 \%$ of dentists report difficulty in communicating with deaf patients [38].

The promotion of comprehensive health care within the context of specialized rehabilitation services and hospitals was the subject of 18 studies [35,37,43,48-51,53,54,56,60-62,66-68,72,73]. Of these, six focussed on the importance of greater integration of multidisciplinary teams in supporting people with disabilities [48,62,66,68,72,73]. Another survey highlighted the need for professionals encouraging recreational activities in order to improve the motor, cognitive, social, emotional, and language skills of children with physical disabilities [60]. An important concern with respect to the inclusion of people intellectual disabilities in rehabilitation services was the difficulty of accessing Psychosocial Care Centres (CAPS) and hospitalization [62]. Exclusions occurred because of lack of confidence of professionals around intellectual impairment that the absence of other reference services that could act as partners for such care.

Gaps in the availability of rehabilitation services were also noted. An evaluation of the degree of implementation of the rehabilitation network in Pernambuco involved eight municipalities with more than 100,000 inhabitants and 27 physical rehabilitation services [54]. It analysed 37 indicators in three dimensions (management, health care, and social control) and concluded that, although there is an expansion of services, the degree of implementation of this network in the state remains insufficient. Another survey limited to the city of Recife focussed on challenges to these services, which included low numbers of services/programs and multidisciplinary teams, lack of technological support, lack of coordination of care, and large gaps in availability of personnel, equipment, and information [50]. Three studies also revealed gaps in referrals and coordination of care between primary care services, rehabilitation services, and hospital units $[49,65,75]$. A central question seems to be whether rehabilitation services should be predominantly based in specialist centres or at the primary care level, as it is the first contact point for the community and supports the coordination of services and information.

Problems with quality of specialist care services for care of people with disabilities was shown through a study in Minas Gerais, with a quality index reaching only $25 \%$ in the items access, social needs, and information received [67]. Quality concerns may be more pronounced for some groups. For instance, two studies showed that people with spinal cord injury faced difficulties due to lack of professional qualifications to care for this group, fragmented care, difficulties in scheduling appointments and exams, difficulties in referral and counter-referral, and inconsistent care [25,65]. Another study highlighted similar problems in the preparation for discharge of people with disabling neurological injury, such as difficulty accessing rehabilitation services and lack of information about the Persons with Disabilities Care Network [49].

Qualitative research that considered the health care network for people with disabilities identified five major themes in the promotion of comprehensive care: rights, citizenship, education, transport, and leisure [24]. For these authors, the achievement of comprehensiveness depends essentially on intersectoral actions. For instance, the lack of accessible transport is a major barrier to accessing healthcare and needs to be improved. Another study confirmed this point, noting that while there were advances in the inclusion of people with disabilities in public policies in Brazil, the focus remained on charitable and biomedical approaches [77]. Social changes are therefore also needed to improve access to comprehensive healthcare for people with disabilities.

\subsubsection{Expansion and Strengthening of Information Mechanisms}

Eight articles considered the availability and quality of information about disability [90-97]. These articles considered both the prevalence and type of disability as well as the living situation of people with disabilities. For instance, one survey collected informa- 
tion on the profile of people with disabilities assisted by the Family Health Strategy and showed that people with disabilities on average have low education and low income and that the most common impairments are due to neurological (43\%), visual (12\%) or hearing $(9 \%)$ impairments, amputation (9\%), or other causes (orthopaedic, mental, and malformations) [93]. The results also showed that most of this group use an auxiliary device and that only a minority (4\%) receives physical therapy treatment. Little information is available from routine data sources. Only two articles collected information from SUS Health Information Systems. The first sought to understand the health needs of people with disabilities from medical records and information systems and showed that many were excluded from work and education and that they had few opportunities to access goods and services [91]. The second study aimed to describe the health profile of hearing-impaired people in the city of São Paulo through data collected at the SUS Department of Informatics [96]. Again, many challenges were identified, for instance, with living conditions, transport, negative attitudes, and experience of situations of violence. There is therefore a lack of information on the lives of people with disabilities, particularly from routine data sources, but available data consistently show large challenges and great unmet needs.

\subsubsection{Human Resource Training}

Human resource training about disability was the focus of 11 articles [98-108], including promotion of skills to care for deaf people (six studies), training of Community Health Agents to register people with disabilities (one); training for assistance to blind people (one); and training to support people with any type of disability (three).

Three studies highlighted the need to include training on disability knowledge and skills in undergraduate health courses [100-102]. One article used qualitative methods to explore feelings of discomfort and unpreparedness of professionals in general to meet the needs of people with hearing loss [102]. It confirmed the lack of readiness of primary care professionals and supports the inclusion of disability in undergraduate courses in health disciplines.

Four articles considered communication barriers as the main difficulty in the delivery of care and the quality of the therapeutic relationship between professional and deaf user $[100,101,107,108]$. The importance of training of health professionals was highlighted, as they reported lacking confidence and preparedness to offer care to this group. They also highlighted good practice examples of individual initiatives of health professionals in training and improving care for people with disabilities, which are independent of public policies. In general, these articles emphasized adequate academic training and the effective implementation of public policies in promoting accessibility and social inclusion of people with disabilities.

\section{Discussion}

This scoping review of the evidence on the experience of people with disabilities in Brazil with respect to the six themes of the PNSPD guidelines highlights two major issues. First, there is a lack of data on the health and healthcare access of people with disabilities in Brazil. Few studies were identified, and those that were available were often small in scale, undertaken locally and in a few key regions (south, southeast, northeast), and focussed on only a few impairment groups. National and regional studies are lacking. Large gaps therefore exist, which need to be filled through further research with respect to groups (e.g., people with intellectual impairments), cross-cutting issues (e.g., gender, race, ethnicity, poverty, culture), geographic areas (e.g., central region, rural versus urban), and topic (e.g., the need for healthcare training and good practice examples). More evidence is needed on the inequalities in healthcare access facing people with disabilities so that appropriate interventions can be developed. In particular, a greater emphasis should be given to the use of routine sources of data for this purpose.

Second, although the policy framework in Brazil supports the inclusion of people with disabilities in healthcare, the available data show that this right does not seem to be realised, 
and large inequalities remain, as has also been noted by other researchers [17]. More efforts are needed to improve accessibility of primary healthcare facilities and linkages with specialist care. Notably, efforts are needed towards the training of healthcare workers on disability, which is specified under the PNSPD but not yet happening in reality. Health and healthcare access are important contributors to quality of life but not the sole determinants. Furthermore, healthcare access is not determined only by the health system, and factors such as poverty, attitudes, and accessible transport are also important. Attempts to improve healthcare access for people with disabilities therefore need to be intersectoral, linking and reinforcing strategies to improve living situations, transport systems, attitudes, and so on. Another important factor is that the inequities facing people with disabilities in Brazil are set against widespread inequalities in healthcare access in Brazil in general. More investigation is needed on the compounding role poverty plays in creating the health inequities for people with disabilities in Brazil and how they can be incorporated into other measures to level up healthcare access.

More efforts are therefore needed to implement evidence-based interventions to improve access to healthcare for people with disabilities in Brazil and thereby reduce inequalities. The PNSPD framework is helpful for guiding this action. These efforts for improvement can also be envisaged from a health system perspective [3]. The governance, meaning policies and laws, are already supportive of the inclusion of people with disabilities in the healthcare system. However, leadership, financing, and evidence need to be strengthened. Furthermore, changes are needed from the demand side (i.e., improving the autonomy, awareness, and affordability of healthcare by people with disabilities) and supply side (i.e., improving human resources availability and skills, accessibility of health facilities, and availability of specialist services). Together, these changes will improve health outputs for people with disabilities and consequently improve outcomes and reduce inequalities. However, more evidence needs to be gathered, both in Brazil and more globally, to document good practice and what works to improve disability-inclusive health.

There are a few limitations to this scoping review. A systematic review was not undertaken given the broad topic scope, and Scopus database was not included due to lack of subscription. Consequently, relevant papers may have been missed. Quality of papers was not considered although this is likely to have been low for many studies included. Furthermore, potentially relevant publications (e.g., theses, dissertations, grey literature) and publications not in English or Portuguese were excluded. There are issues with the generalisability of findings, as the studies included are mostly concentrated in the southeast and northeast regions and carried out at municipal and local levels although the objective was to analyse the national scenario regarding the health care of people with disabilities.

\section{Conclusions}

The policy framework in Brazil is supportive of the inclusion of people with disabilities in health services, and there has been some progress in the scaling up of rehabilitation services. However, large inequalities remain due to poor implementation of the policy into practice. In particular, there are issues with accessibility of services, lack of coordination of care, poor healthcare worker knowledge, and lack of information on disability, which collectively weaken the realisation of the right to health and perpetuate health inequalities. There is an urgent need for the Brazilian State to implement and expand the strategic actions of the PNSPD, promoting the quality of life of this population to repair the history of inequality of opportunities for these people.

Author Contributions: Conceptualization, M.A.O.d.C., H.F.S., M.E.L.d.C., G.M.D.M., M.d.S.V.d.A., R.S.d.O., A.F.C.d.A. and T.M.L.; methodology, M.A.O.d.C., H.F.S., M.E.L.d.C., G.M.D.M., M.d.S.V.d.A., R.S.d.O. and T.M.L.; formal analysis, M.A.O.d.C., H.F.S. and M.E.L.d.C.; investigation, M.A.O.d.C., H.F.S. and M.E.L.d.C.; data curation, M.A.O.d.C., H.F.S. and M.E.L.d.C.; writing-original draft preparation, M.A.O.d.C., H.F.S. and M.E.L.d.C.; writing-review and editing, M.A.O.d.C., H.F.S., M.E.L.d.C., G.M.D.M., M.d.S.V.d.A., R.S.d.O., L.P.-K., H.K. and T.M.L.; supervision, M.d.S.V.d.A., L.P.-K., H.K. and T.M.L.; project administration, M.d.S.V.d.A., A.F.C.d.A., L.P.-K., H.K. and T.M.L.; 
funding acquisition, A.F.C.d.A., H.K. and T.M.L. All authors have read and agreed to the published version of the manuscript.

Funding: This research was funded by CONFAP-MRC, grant number MR/R022755/1.

Institutional Review Board Statement: Ethical review and approval were waived for this study, as it was a scoping review.

Informed Consent Statement: Not applicable.

Data Availability Statement: Not applicable.

Conflicts of Interest: The authors declare no conflict of interest.

\section{References}

1. UN. Convention on the Rights of Persons with Disabilities; UN: New York, NY, USA, 2006.

2. WHO. World Report on Disability; WHO: Geneva, Switzerland, 2011.

3. Kuper, H.; Heydt, P. The Missing Billion. Missing Billion, 2019. Available online: https://www.themissingbillion.org/the-report-2 (accessed on 26 January 2022).

4. Brazil. Constitution of the Federative Republic of Brazil. 1988. Available online: https://www.oas.org/es/sla/ddi/docs/acceso_ informacion_base_dc_leyes_pais_b_1_en.pdf (accessed on 26 January 2022).

5. Brazil. Portaria Ministerial N 1060 ; Ministério da Saúde: Brasília, Brazil, 2002. Available online: https://bvsms.saude.gov.br/ bvs/saudelegis/gm/2002/prt1060_05_06_2002.html (accessed on 5 August 2021).

6. Súmula do Programa "Viver Sem Limite": Plano Nacional Dos Direitos Da Pessoa Com Deficiência. Cad. CEDES 2014, 34, 263-266. [CrossRef]

7. Santos, C.C.; Pedde, V.; Junior, N.K.; Renner, J.S. Política Pública, Deficiência Física, Concessão De Órteses, Próteses e Meios de Locomoção no Rio Grande do Sul: Período Pré/Pós Plano Viver Sem Limites. Interfaces Científicas Saúde Ambiente 2017, 5, 17-26. [CrossRef]

8. Brasil; Instituto Brasileiro De Geografia E Estatística (IBGE). Pesquisa Nacional de Saúde 2019-ciclos de vida. 2021. Available online: https://biblioteca.ibge.gov.br/visualizacao/livros/liv101846.pdf (accessed on 26 January 2022).

9. Tricco, A.C.; Lillie, E.; Zarin, W.; O’Brien, K.K.; Colquhoun, H.; Levac, D.; Straus, S.E. PRISMA extension for scoping reviews (PRISMA-ScR): Checklist and explanation. Ann. Intern. Med. 2018, 169, 467-473. [CrossRef]

10. Paes, A.T. Por dentro da estatística. Einstein. Educ. Contin. Saúde 2008, 6, 107-108.

11. Galvão, C.R.C.; de Lima Barroso, B.I.; de Castro Grutt, D. A tecnologia assistiva e os cuidados específicos na concessão de cadeiras de rodas no Estado do Rio Grande do Norte/Assistive Technology and specific care in the granting of wheelchairs in Rio Grande do Norte state. Cad. Bras. Ter. Ocup. 2013, 21, 11-18.

12. Varela, R.C.B.; Oliver, F.C. A utilização de Tecnologia Assistiva na vida cotidiana de crianças com deficiência. Ciên. Saúde Colet. 2013, 18, 1773-1784. [CrossRef]

13. Castro, S.S.; Lefèvre, F.; Lefèvre, A.M.C.; Cesar, C.L.G. Acessibilidade aos serviços de saúde por pessoas com deficiência. Rev. Saúde Pública 2011, 45, 99-105. [CrossRef]

14. Amaral, F.L.J.D.S.; Holanda, C.M.D.A.; Quirino, M.A.B.; Nascimento, J.P.D.S.; Neves, R.D.F.; Ribeiro, K.S.Q.S.; Alves, S.B. Acessibilidade de pessoas com deficiência ou restrição permanente de mobilidade ao SUS. Ciên. Saúde Colet. 2012, 17, 1833-1840. [CrossRef]

15. Peixoto, M.V.D.S.; Santos, G.S.; Nobre, G.R.D.; Novais, A.P.D.S.; Reis, P.M. Análise da participação popular na política de atenção à saúde da pessoa com deficiência em Aracaju, Sergipe, Brasil. Interface Comun. Saúde Educ. 2018, 22, 1099-1110. [CrossRef]

16. Nobrega, J.D.; Munguba, M.C.; Pontes, R.J.S. Atenção à saúde e surdez: Desafios para implantação da rede de cuidados à pessoa com deficiência. Rev. Bras. Promoção Saúde 2017, 30, 1-10. [CrossRef]

17. Siqueira, F.C.V.; Facchini, L.A.; Silveira, D.S.D.; Piccini, R.X.; Thumé, E.; Tomasi, E. Barreiras arquitetônicas a idosos e portadores de deficiência física: Um estudo epidemiológico da estrutura física das unidades básicas de saúde em sete estados do Brasil. Ciên. Saúde Colet. 2009, 14, 39-44. [CrossRef]

18. Vieira, C.M.; Caniato, D.G.; Yonemotu, B.P.R. Comunicação e acessibilidade: Percepções de pessoas com deficiência auditiva sobre seu atendimento nos serviços de saúde. RECIIS 2017, 11, 2-12. [CrossRef]

19. Martins, K.P.; Costa, T.F.D.; Medeiros, T.M.D.; Fernandes, M.D.G.M.; França, I.S.X.D.; Costa, K.N.D.F.M. Estrutura interna de Unidades de Saúde da Família: Acesso para as pessoas com deficiência. Ciên. Saúde Colet. 2016, 21, 3153-3160. [CrossRef]

20. Aragão, A.E.D.A.; Pagliuca, L.M.F.; Macêdo, K.N.D.F.; DE ALMEIDA, P.C. Instalações sanitárias, equipamentos e áreas de circulação em Hospitais: Adequações aos deficientes físicos. Rev. Rene 2008, 9, 36-44.

21. Mazzarotto, I.H.E.K.; Gonçalves, C.G.D.O.; Bellia, C.G.D.L.; Moretti, C.A.M.; Iantas, M.R. Integralidade do cuidado na atenção à saúde auditiva do adulto no SUS: Acesso à reabilitação. Audiol. Commun. 2019, 24, e2009. [CrossRef]

22. Battistella, L.R.; Juca, S.S.H.; Tateishi, M.; Oshiro, M.S.; Yamanaka, E.I.; Lima, E.; Ramos, V.D. Lucy Montoro Rehabilitation Network mobile unit: An alternative public healthcare policy. Disabil. Rehabil. Assist. Technol. 2015, 10, 309-315. [CrossRef] 
23. Vasconcelos, L.R.; Pagliuca, L.M.F. Mapeamento da acessibilidade do portador de limitação física a serviços básicos de saúde. Esc. Anna Nery Rev. Enferm 2006, 10, 494-500. [CrossRef]

24. Othero, M.B.; Ayres, J.R.D.C.M. Necessidades de saúde da pessoa com deficiência: A perspectiva dos sujeitos por meio de histórias de vida. Interface Comun. Saúde Educ. 2012, 16, 219-234. [CrossRef]

25. Aoki, M.; Correa Oliver, F. Pessoas com deficiência moradoras de bairro periférico da cidade de São Paulo: Estudo de suas necessidades. Cad. Ter. Ocup. 2013, 21, 391-398. [CrossRef]

26. França, I.S.X.D.; Coura, A.S.; Sousa, F.S.D.; Almeida, P.C.D.; Pagliuca, L.M.F. Qualidade de vida em pacientes com lesão medular Rev. Gaúch. Enferm. 2013, 34, 155-163. [CrossRef]

27. Mattevi, B.S.; Bredemeier, J.; Fam, C.; Fleck, M.P. Quality of care, quality of life, and attitudes toward disabilities: Perspectives from a qualitative focus group study in Porto Alegre, Brazil. Rev. Panam. Salud Pública 2012, 31, 188-196. [CrossRef]

28. Miguel, J.H.D.S.; Novaes, B.C.D.A.C. Reabilitação auditiva na criança: Adesão ao tratamento e ao uso do aparelho de amplificação sonora individual. Audiol. Commun. 2013, 18, 171-178. [CrossRef]

29. Guia, A.C.D.O.M.; Oliveira Neto, R.D.; Escarce, A.G.; Lemos, S.M.A. Rede de Atenção à Saúde Auditiva: Perspectiva do usuário. Distúrb. Comun. 2016, 28, 473-482.

30. Camargos, A.C.R.; Lacerda, T.T.B.D.; Barros, T.V.; Silva, G.C.D.; Parreiras, J.T.; Vidal, T.H.D.J. Relação entre independência funcional e qualidade de vida na paralisia cerebral. Fisioter. Mov. 2012, 25, 83-92. [CrossRef]

31. Ruschel, N.L.; Bonatto, A.S.; Teixeira, A.R. Reposição de próteses auditivas em programa de saúde auditiva. Audiol. Commun. 2019, 24, e2025. [CrossRef]

32. Barbosa, M.R.; Medeiros, D.D.S.; Ribeiro, G.M.; Rossi-Barbosa, L.A.R.; Caldeira, A.P. Satisfação com Aparelhos de Amplificação Sonora Individual entre usuários de serviços de saúde auditiva. Audiol. Commun. 2013, 18, 260-267.

33. Fiorati, R.C.; Elui, V.M.C. Social determinants of health, inequality and social inclusion among people with disabilities. Rev. Latino Am. Enferm. 2015, 23, 329-336. [CrossRef]

34. França, I.S.X.D.; Pagliuca, L.M.F.; Baptista, R.S.; França, E.G.D.; Coura, A.S.; Souza, J.A.D. Violência simbólica no acesso das pessoas com deficiência às unidades básicas de saúde. Rev. Bras. Enferm. 2010, 63, 964-970. [CrossRef]

35. Góes, F.G.B.; Cabral, I.E. A alta hospitalar de crianças com necessidades especiais de saúde e suas diferentes dimensões [Hospital discharge in children with special health care needs and its different dimensions]. Rev. Enferm. UERJ 2017, 25, e18684. [CrossRef]

36. Adamy, E.; Krauzer, I.; Hillesheim, C.; Silva, B.; Garghetti, F. A inserção da sistematização da assistência de enfermagem no contexto de pessoas com necessidades especiais. Rev. Pesqui. Cuid. Fundam. 2013, 5, 53-65.

37. Sousa, K.D.M.; de Oliveira, W.I.F.; de Melo, L.O.M.; Alves, E.A.; Piuvezam, G.; Gama, Z.A.D.S. A qualitative study analyzing access to physical rehabilitation for traffic accident victims with severe disability in Brazil. Disabil. Rehabil. 2017, 39, 568-577. [CrossRef]

38. Rocha, L.L.; De Lima Saintrain, M.V.; Vieira-Meyer, A.P.G.F. Access to dental public services by disabled persons. BMC Oral Health 2015, 15, 35. [CrossRef]

39. De Aragão, A.K.R.; Sousa, A.; Silva, K.; Vieira, S.; Colares, V. Acessibilidade da criança e do adolescente com deficiência na atenção básica de saúde bucal no serviço público: Estudo piloto. Pesqui. Bras. Odontopediatria Clín. Integr. 2011, 11, 159-164. [CrossRef]

40. de Rosário, S.S.D.; de Lima Fernandes, A.P.N.; Batista, F.W.B.; Monteiro, A.I. Acessibilidade de crianças com deficiência aos serviços de saúde na atenção primária. Rev. Eletrônica Enferm. 2013, 15, 738-744. [CrossRef]

41. Girondi, J.B.R.; dos Santos, S.M.A.; de Almeida Hammerschmidt, K.S.; Tristão, F.R. Acessibilidade de idosos com deficiência física na atenção primária. Estud. Interdiscip. Envelhec. 2014, 19, 825-837. [CrossRef]

42. Gomes, T.M.; Costa, K.N.F.M.; Costa, T.F.; Martins, K.P.; Dantas, T.R.A. Acessibilidade de pessoas com deficiência visual nos serviços de saúde [Health service accessibility for the visually impaired] [Accesibilidad para las personas con discapacidad visual en los servicios de salud]. Rev. Enferm. UERJ 2017, 25, 11424. [CrossRef]

43. Pagliuca, L.M.F.; Aragão, A.E.D.A.; Almeida, P.C. Acessibilidade e deficiência física: Identificação de barreiras arquitetônicas em áreas internas de hospitais de Sobral, Ceará. Rev. Esc. Enferm. USP 2007, 41, 581-588. [CrossRef]

44. Marques, J.F.; Áfio, A.C.E.; Carvalho, L.V.D.; Leite, S.D.S.; Almeida, P.C.D.; Pagliuca, L.M.F. Acessibilidade física na atenção primária à saúde: Um passo para o acolhimento. Rev. Gaúcha Enferm. 2018, 39, e2017-0009. [CrossRef]

45. Lawrence, H.; de Paula Sousa, L.; de Lima Gonçalves, F.; de Lima Saintrain, M.V.; Vieira, A.P.G.F. Acesso à saúde bucal pública pelo paciente especial: A ótica do cirurgião-dentista. Rev. Bras. Promoç. Saúde 2014, 27, 190-197. [CrossRef]

46. Macêdo, G.L.D.; Lucena, E.E.D.S.; Lopes, I.K.R.; Batista, L.T.D.O. Acesso ao Atendimento Odontológico dos Pacientes Especiais: A Percepção de Cirurgiões-Dentistas da Atenção Básica. 2018. (accessed on 26 January 2022).

47. Ianni, A.; Pereira, P.C.A. Acesso da comunidade surda à rede básica de saúde. Saúde Soc. 2009, 18, 89-92. [CrossRef]

48. Freire, D.B.; Gigante, L.P.; Béria, J.U.; Palazzo, L.D.S.; Figueiredo, A.C.L.; Raymann, B.C.W. Acesso de pessoas deficientes auditivas a serviços de saúde em cidade do Sul do Brasil. Cad. Saúde Pública 2009, 25, 889-897. [CrossRef] [PubMed]

49. Machado, W.C.A.; Silva, V.M.D.; Silva, R.A.D.; Ramos, R.L.; Figueiredo, N.M.A.D.; Branco, E.M.D.S.C.; Carreiro, M.D.A. Alta hospitalar de clientes com lesão neurológica incapacitante: Impreteríveis encaminhamentos para reabilitação. Ciên. Saúde Colet. 2016, 21, 3161-3170. [CrossRef] [PubMed]

50. Lima, M.L.C.D.; Deslandes, S.F.; Souza, E.R.D.; Lima, M.L.L.T.D.; Barreira, A.K. Análise diagnóstica dos serviços de reabilitação que assistem vítimas de acidentes e violências em Recife. Ciên. Saúde Colet. 2009, 14, 1817-1824. [CrossRef] [PubMed] 
51. de Araujo Dantas, M.S.; da Nobrega, V.M.; dos Santos Fechine, C.P.N.; Torquato, I.M.B.; de Assis, W.D.; Collet, N. Atenção profissional à criança com paralisia cerebral e sua família [Professional care for children with cerebral palsy and their families] [Atención profesional al niño con parálisis cerebral ya su familia]. Rev. Enferm. UERJ 2017, 25, 18331.

52. Quaresma, F.R.P.; Stein, A.T. Attributes of primary health care provided to children/adolescents with and without disabilities. Ciên. Saúde Colet. 2015, 20, 2461-2468. [CrossRef]

53. Guia, A.C.D.O.M.; Escarce, A.G.; Lemos, S.M.A. Autopercepção de saúde de usuários da Rede de Atenção à Saúde Auditiva. Cad. Saúde Coletiva 2018, 26, 410-417. [CrossRef]

54. Lima, M.L.L.T.D.; Lima, M.L.C.D. Avaliação da implantação de uma Rede Estadual de Reabilitação Física em Pernambuco na perspectiva da Política Nacional de Redução da Morbimortalidade por Acidentes e Violência, 2009. Epidemiol. Serv. Saúde 2013, 22, 597-607. [CrossRef]

55. Souza, M.A.P.D.; Dias, J.F.; Ferreira, F.R.; Mancini, M.C.; Kirkwood, R.N.; Sampaio, R.F. Características e demandas funcionais de usuários de uma rede local de reabilitação: Análise a partir do acolhimento. Ciên. Saúde Colet. 2016, 21, 3277-3286. [CrossRef]

56. Bevilacqua, M.C.; Morettin, M.; De Melo, T.M.; Amantini, R.C.B.; Martinez, M.A.N.D.S. Contribuições para análise da política de saúde auditiva no Brasil. Rev. Soc. Bras. Fonoaudiol. 2011, 16, 252-259. [CrossRef]

57. Schultz, T.G.; do Carmo Alonso, C.M. Cuidado da criança com deficiência na Atenção Primária à Saúde. Cad. Ter. Ocup. UFSCar 2016, 24, 611. [CrossRef]

58. Aoki, M.; Batista, M.P.P.; Almeida, M.H.M.; Molini-Avejonas, D.R.; Oliver, F.C. Desafios do cuidado em rede na percepção de preceptores de um Pet Redes em relação à pessoa com deficiência e bebês de risco: Acesso, integralidade e comunicação/Challenges on network care considering the perceptions of preceptors of a Pet-Network regarding people with disabilities and at-risk infants: Access, comprehensiveness and communication. Cad. Bras. Ter. Ocup. 2017, 25, 519-532.

59. Antunes, M.H.; Rocha, E.F. Desbravando novos territórios: Incorporação da Terapia Ocupacional na estratégia da Saúde da Família no município de São Paulo e a sua atuação na atenção à saúde da pessoa com deficiência-no período de 2000-2006. Rev. Ter. Ocup. 2011, 22, 270-278. [CrossRef]

60. Bataglion, G.A.; Marinho, A. Familiares de crianças com deficiência: Percepções sobre atividades lúdicas na reabilitação. Ciên. Saúde Colet. 2016, 21, 3101-3110. [CrossRef] [PubMed]

61. Rezende, C.F.D.; Carvalho, S.A.D.S.; Maciel, F.J.; Oliveira, R.D.; Pereira, D.V.T.; Lemos, S.M.A. Rede de saúde auditiva: Uma análise espacial. Braz. J. Otorhinolaryngol. 2015, 81, 232-239.

62. Surjus, L.T.D.L.E.S.; Onocko-Campos, R.T. Indicadores de avaliação da inserção de pessoas com deficiência intelectual na Rede de Atenção Psicossocial. Saúde Debate 2017, 41, 60-70. [CrossRef]

63. Nicolau, S.M.; Schraiber, L.B.; Ayres, J.R.D.C.M. Mulheres com deficiência e sua dupla vulnerabilidade: Contribuições para a construção da integralidade em saúde. Ciên. Saúde Colet. 2013, 18, 863-872. [CrossRef]

64. Cardoso, A.M.R.; de Araújo Brito, D.B.; Alves, V.F.; Padilha, W.W.N. O acesso ao cuidado em saúde bucal para crianças com deficiência motora: Perspectivas dos cuidadores. Pesqui. Bras. Odontopediatria Clín. Integr. 2011, 11, 593-599. [CrossRef]

65. de França, I.S.X.; Baptista, R.S.; da Silva Abrão, F.M.; Coura, A.S.; de França, E.G.; Pagliuca, L.M.F. O des-cuidar do lesado medular na atenção básica: Desafios bioéticos para as políticas de saúde. Rev. Bras. Enferm. 2012, 65, $236-243$.

66. Oliveira, A.C.; Czeresnia, D.; Paiva, S.M.; Campos, M.R.; Ferreira, E.F. Uso de serviços odontológicos por pacientes com síndrome de Down. Rev. Saúde Pública 2008, 42, 693-699. [CrossRef]

67. Dias, T.E.C.; Friche, A.A.D.L.; Lemos, S.M.A. Percepção quanto à qualidade do cuidado de usuários da Rede de Cuidados à Pessoa com Deficiência. CoDAS 2019, 31, e20180102. [CrossRef]

68. Dubow, C.; Garcia, E.L.; Krug, S.B.F. Percepções sobre a Rede de Cuidados à Pessoa com Deficiência em uma Região de Saúde. Saúde Debate 2018, 42, 455-467. [CrossRef]

69. Othero, M.B.; Dalmaso, A.S.W. Pessoas com deficiência na atenção primária: Discurso e prática de profissionais em um centro de saúde-escola. Interface Comun. Saúde Educ. 2009, 13, 177-188. [CrossRef]

70. Martins, E.S.; de Andrade Trindade, J.L. Pet-saúde redes de atenção a pessoa com deficiência no contexto da atenção primária de saúde: Reflexões sobre a deficiência e funcionalidade do sujeito. Saúde Redes 2018, 4, 115-126.

71. Almeida, M.H.M.D.; Pacheco, S.; Krebs, S.; Oliveira, A.M.; Samelli, A.; Molini-Avejonas, D.R.; Oliver, F.C. Primary health care assessment by users with and without disabilities. CoDAS 2017, 29, e20160225. [PubMed]

72. Vianna, N.G.; Cavalcanti, M.D.L.T.; Acioli, M.D. Princípios de universalidade, integralidade e equidade em um serviço de atenção à saúde auditiva. Ciên. Saúde Colet. 2014, 19, 2179-2188. [CrossRef]

73. Cunha, T.E.O.; Leopardi, M.T.; Schoeller, S.D. Processo de trabalho em reabilitação de pessoas com deficiência física. Rev. Baiana Enferm. 2015, 29, 339-349. [CrossRef]

74. Barbieri, M.C.; Broekman, G.V.D.Z.; Souza, R.O.D.D.; Lima, R.A.G.D.; Wernet, M.; Dupas, G. Rede de suporte da família da criança e adolescente com deficiência visual: Potencialidades e fragilidades. Ciên. Saúde Colet. 2016, 21, 3213-3223. [CrossRef]

75. Pereira, J.D.S.; Machado, W.C.A. Referência e contrarreferência entre os serviços de reabilitação física da pessoa com deficiência: A (des) articulação na microrregião Centro-Sul Fluminense, Rio de Janeiro, Brasil. Physis 2016, 26, 1033-1051. [CrossRef]

76. Van Schaik, E.E.; Souza, C.C.B.X.; Rocha, E.F. Reflexões sobre a atenção às crianças com deficiência na atenção. Rev. Ter. Ocup. Univ. São Paulo 2014, 25, 233. [CrossRef]

77. Ursine, B.L.; Pereira, É.L.; Carneiro, F.F. Saúde da pessoa com deficiência que vive no campo: O que dizem os trabalhadores da Atenção Básica? Interface Comun. Saúde Educ. 2017, 22, 109-120. [CrossRef] 
78. Sabbag, J.C.; Lacerda, A.B.M.D. Rastreamento e monitoramento da Triagem Auditiva Neonatal em Unidade de Estratégia de Saúde da Família: Estudo-piloto. CoDAS 2017, 29, 1-7. [CrossRef] [PubMed]

79. Rovere, N.C.; Lima, M.C.M.P.; Silva, I.R. A comunicação entre sujeitos surdos com diagnóstico precoce e com diagnóstico tardio e seus pares. Distúrb. Comun. 2018, 30, 90-102. [CrossRef]

80. Rodrigues, G.R.I.; Loiola-Barreiro, C.M.; Pereira, T.; Pomilio, M.C.A. A triagem auditiva neonatal antecipa o diagnóstico e a intervenção em crianças com perda auditiva? Audiol. Commun. 2015, 20, 246-254. [CrossRef]

81. Lima, P.T.; Goldbach, M.G.; Monteiro, M.C.; Ribeiro, M.G. A triagem auditiva neonatal na Rede Municipal do Rio de Janeiro, Brasil. Ciên. Saúde Colet. 2015, 20, 57-63. [CrossRef]

82. Françozo, M.D.F.D.C.; Masson, G.A.; Rossi, T.R.D.F.; Lima, M.C.M.P.; Santos, M.F.C.D. Adesão a um programa de triagem auditiva neonatal. Saúde Soc. 2010, 19, 910-918. [CrossRef]

83. da Silva, W.C.F.G.; Paschoal, M.R.; Cavalcanti, H.G. Análise da cobertura da triagem auditiva neonatal no Nordeste brasileiro. Audiol. Commun. 2017, 22, 1-7.

84. Bertoldi, P.M.; Manfredi, A.K.S.; Mitre, E.I. Análise dos resultados da triagem auditiva neonatal no município de Batatais. Medicina 2017, 50, 150-157.

85. Nascimento, G.C.C.D.; Gagliardo, H.G.R.G. Atenção à saúde ocular de crianças com alterações no desenvolvimento em serviços de intervenção precoce: Barreiras e facilitadores. Rev. Bras. Oftalmol. 2016, 75, 370-375. [CrossRef]

86. Muniz, L.; Caldas Neto, S.D.S.; Gouveia, M.D.C.L.; Albuquerque, M.; Aragão, A.; Mercês, G.; Araújo, B. Conhecimento de ginecologistas e pediatras de hospitais públicos do Recife a respeito dos fatores de risco para surdez. Braz. J. Otorhinolaryngol. 2010, 76, 510-516. [CrossRef]

87. Bittencourt, Z.Z.L.D.C.; Montilha, R.D.C.L.; Gasparetto, M.E.R.F.; Temporini, E.R.; Carvalho, K.M.M.D. Retinopatia diabética e deficiência visual entre pacientes de programa de reabilitação. Rev. Bras. Oftalmol. 2011, 70, 342-348. [CrossRef]

88. Miranda, G.M.D.; Queiroga, B.A.M.D.; Lessa, F.J.D.; Leal, M.D.C.; Caldas Neto, S.D.S. Diagnóstico da deficiência auditiva em Pernambuco: Oferta de serviços de média complexidade-2003. Rev. Bras. Oftalmol. 2006, 72, 581-586. [CrossRef]

89. Pinto, M.M.; Raimundo, J.C.; Samelli, A.G.; Carvalho, A.C.M.D.; Matas, C.G.; Ferrari, G.M.D.S.; Bento, R.F. Idade no diagnóstico e no início da intervenção de crianças deficientes auditivas em um serviço público de saúde auditiva brasileiro. Arq. Int. Otorrinolaringol. 2012, 16, 44-49. [CrossRef]

90. Alves, G.V.; de Oliveira Lomba, G.; Barbosa, T.A.; Reis, K.M.N.; Braga, P.P. Crianças com necessidades especiais de saúde de um município de Minas Gerais: Estudo descritivo. Rev. Enferm. Cent. Oeste Min. 2014, 4, 1310-1321.

91. de Mello Rodrigues, S.; Aoki, M.; Oliver, F.C. Diagnóstico situacional de pessoas com deficiência acompanhadas em terapia ocupacional em uma unidade básica de saúde/Situational diagnosis of people with disabilities, receiving occupational therapy service in a basic health unit. Cad. Bras. Ter. Ocup. 2015, 23, 781-794. [CrossRef]

92. Nogueira, G.C.; Schoeller, S.D.; Ramos, F.R.D.S.; Padilha, M.I.; Brehmer, L.C.D.F.; Marques, A.M.F.B. Perfil das pessoas com deficiência física e Políticas Públicas: A distância entre intenções e gestos. Ciên. Saúde Colet. 2016, 21, 3131-3142. [CrossRef] [PubMed]

93. Bim, C.R.; Benato, B.S.; Vicentim, T.K. Perfil dos deficientes atendidos pelo programa de saúde da família. Do município de Guarapuava-Paraná. Ciên. Cuid. Saúde 2007, 6, 390-396.

94. Sales, C.B.; Almeida, E.M.D.S.; Silva, G.K.; Alves, L.M. Perfil dos usuários do sistema de frequência modulada de um serviço de atenção à saúde auditiva. Audiol. Commun. 2019, 24, 1-7. [CrossRef]

95. Souza, F.D.R.; Pimentel, A.M. Pessoas com deficiência: Entre necessidades e atenção à saúde. Cad. Ter. Ocup. UFSCar 2012, 20, 229-237. [CrossRef]

96. Vieira, G.I.; Mendes, B.D.C.A.; Zupelari, M.M.; Pereira, I.M.T.B. Saúde auditiva no Brasil: Análise quantitativa do período de vigência da Política Nacional de Atenção à Saúde Auditiva. Distúrb. Comun. 2015, 27, 725-740.

97. Lopes, M.J.M.; Soares, J.D.S.F.; Bohusch, G. Usuários portadores de deficiência: Questões para a atenção primária de saúde. Rev. Baiana Enferm. 2014, 1, 4-12.

98. Maia, E.R.; Pagliuca, L.M.F.; Almeida, P.C.D. Aprendizagem do agente comunitário de saúde para identificar e cadastrar pessoas com deficiência. Acta Paul. Enferm. 2014, 27, 326-332. [CrossRef]

99. Soares, J.R.; Pagliuca, L.M.F.; Barbosa, E.M.G.; Maia, E.R. Aquisição de conhecimento para comunicação na consulta de enfermagem com o cego. Rev. Rene 2018, 19, 1-9.

100. Gomes, L.F.; Machado, F.C.; Lopes, M.M.; Oliveira, R.S.; Medeiros-Holanda, B.; Silva, L.B.; Kandratavicius, L. Conhecimento de Libras pelos médicos do Distrito Federal e atendimento ao paciente surdo. Rev. Bras. Educ. Méd. 2017, 41, 390-396. [CrossRef]

101. Tedesco, J.D.R.; Junges, J.R. Desafios da prática do acolhimento de surdos na atenção primária. Cad. Saúde Pública 2013, 29, 1685-1689. [CrossRef]

102. de França, E.G.; Pontes, M.A.; Costa, G.M.C.; de França, I.S.X. Dificuldades de profissionais na atenção à saúde da pessoa com surdez severa. Cienc. Enferm. 2016, 22, 107-116. [CrossRef]

103. Trombetta, A.P.; Ramos, F.R.S.; Vargas, M.A.D.O.; Marques, A.M.B. Experiências da equipe de centro de reabilitação-o real do trabalho como questão ética. Esc. Anna Nery 2015, 19, 446-453.

104. Missel, A.; Costa, C.C.D.; Sanfelice, G.R. Humanização da saúde e inclusão social no atendimento de pessoas com deficiência física. Trab. Educ. Saúde 2017, 15, 575-597. [CrossRef] 
105. Sales, A.S.; Oliveira, R.F.D.; Araújo, E.M.D. Inclusion of persons with disabilities in a Reference Center for STD/AIDS of a town in Bahia, Brazil. Rev. Bras. Enferm. 2013, 66, 208-214. [CrossRef]

106. Reis, V.D.S.L.; Santos, A.M.D. Knowledge and experience of Family Health Team professionals in providing healthcare for deaf people. Rev. CEFAC 2019, 21, e5418. [CrossRef]

107. Pereira, R.M.; de Amorim Monteiro, L.P.; da Costa Monteiro, A.C.; Costa, I.D.C.C. Percepção das pessoas surdas sobre a comunicação no atendimento odontológico. Rev. Ciênc. Plur. 2017, 3, 53-72. [CrossRef]

108. Santos, A.S.; Portes, A.J.F. Perceptions of deaf subjects about communication in Primary Health Care. Rev. Latinoam. Enferm. 2019, 27, e3127. [CrossRef] [PubMed] 